\title{
PENGADAAN ECO-LIBRARY BERBASIS PENGELOLAAN SAMPAH DI DESA KILENSARI KECAMATAN PANARUKAN KABUPATEN SITUBONDO, JAWA TIMUR
}

\author{
Endang Suhesti ${ }^{1)}$ Siti Muyasaroh ${ }^{2)}$ \\ hesty_soehardjo@yahoo.co.id ${ }^{1)}$; muyassaroh.siti.sm@gmail.com ${ }^{2)}$ \\ Dosen Fakultas Pertanian, Universitas Abdurachman Saleh Situbondo
}

\begin{abstract}
This activity was aimed to solve the problems related to the lack of awareness and understanding of the community in Kilensari Village, Panarukan Subdistrict on proper waste management. Based on preliminary observations, people dump garbage around the river mouth area. It caused environmental degradation, threats to aquatic organisms, and risks to human health. To overcome this, the proposed establishment of eco-library as a means of education and socialization to the community for better waste management. The establishment of an eco-library involves NGOs engaging in environmental literacy, Greenbooks.org. This NGO acts as an online instructor on environmental education activities provided. Based on interviews with Head of Kilensari Village, there has been a plan for making temporary garbage collection (TPS) in Kilensari Village which will be built in 2018 with total area of $\pm 3 \mathrm{Ha}$. The socialization of ecolibrary was held on 15 November 2017 at Kilensari Village Hall, Panarukan Sub-district. Communities participating in the socialization activities were quite enthusiastic about the establishment of an eco-library and a plan of cooperation with Greenbooks.org for environmental learning for children. It is hoped that socialization and training activities related to waste management can continue, so that people understand and implement waste management properly. Initially, the eco-library was proclaimed to have a collection of waste management-based books targeting children's readers aged 6-18. But as the program progresses, the books are not specially discussed about waste management, but still themed environment and living creatures. Cooperation with Greenbooks.org will begin with registration of eco-library in Kilensari Village.
\end{abstract}

Keywords: eco-library, waste management, TPS

\section{PENDAHULUAN}

Pertumbuhan penduduk yang cukup pesat telah mengakibatkan meningkatnya jumlah timbulan sampah. Sampah adalah sisa kegiatan sehari-hari manusia dan/ atau proses alam yang berbentuk padat. Sampah yang dibuang ke lingkungan akan menimbulkan masalah bagi kehidupan dan kesehatan lingkungan, terutama kesehatan manusia. Pengelolaan sampah telah diatur dalam Undang-undang Republik Indonesia Nomor 18 Tahun 2008, namun dalam pelaksanaannya masih terkendala banyak faktor, seperti sarana prasarana, pembiayaan, dan tingkat kesadaran masyarakat yang rendah. beberapa masalah yang ditimbulkan akibat pengelolaan sampah yang kurang tepat antara lain masalah estetika, timbulnya penyakit, bau yang tidak sedap, penyumbatan saluran air dan sungai, serta timbulnya lindi/ leachate (Damanhuri dan Padmi, 2011). 
Situbondo merupakan daerah pesisir dengan garis pantai kurang lebih $158 \mathrm{~km}$ di wilayah pantai utara Jawa. Desa Kilensari, Kecamatan Panarukan, Kabupaten Situbondo merupakan salah satu desa di wilayah pesisir. Karena elevasinya yang cukup rendah dan berbatasan langsung dengan pantai, maka setiap terjadi hujan lebat dan bulan purnama (pasang tertinggi) akan terjadi banjir rob. Air laut yang masuk berasal dari muara yang berada di belakang perkampungan. Permasalahan ini diperparah dengan pengelolaan sampah yang kurang baik. Masyarakat langsung membuang sampah ke area muara. Salah satu alasannya adalah tidak adanya petugas kebersihan yang bertugas mengangkut sampah ke Tempat Pemrosesan Akhir (TPA).

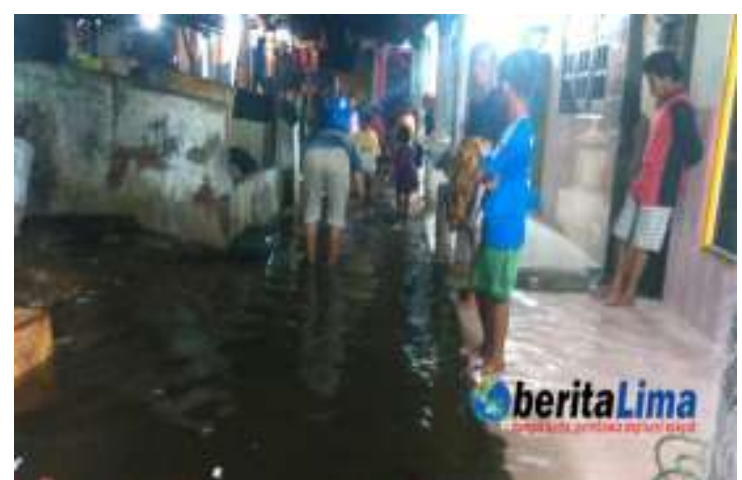

Gambar 1. Banjir rob di Desa Kilensari yang terjadi setiap tahun (sumber:https://www.beritalima.com/2016/12/13/puluhan-kk-panarukanterpaksa-begadang-akibat-banjir-rob/)

Pemerintah Daerah melalui Dinas Lingkungan Hidup berencana akan membangun Tempat Pembuangan Sementara (TPS) di Desa Kilensari, Kecamatan Panarukan, Kabupaten Situbondo pada tahun 2018. Dalam hal ini diperlukan pembentukan sikap, karakter dan kebiasaan untuk mengelola sampah dengan baik, salah satunya dengan mengurangi timbulan sampah, menggunakan kembali dan mendaur ulang botol-botol bekas atau jenis sampah lain yang masih dapat dimanfaatkan, serta membiasakan tidak membuang sampah ke badan air. Pembentukan sikap, karakter dan kebiasaan dalam mengelola sampah dengan benar dapat dilakukan dengan transfer ilmu kepada masyarakat, salah satunya melalui pengadaan bacaan bertema lingkungan serta penyuluhan dan kegiatankegiatan edukatif.

Oleh karena itu, kami selaku peneliti mengajukan suatu solusi dengan mitra di atas dalam bentuk Pengabdian Kepada Masyarakat "Pengadaan Eco-Library 
Berbasis Pengelolaan Sampah Di Desa Kilensari, Kecamatan Panarukan, Kabupaten Situbondo".

\section{METODE PELAKSANAAN}

Pelaksanaan kegiatan pengabdian kepada masyarakat di Desa Kilensari dibagi menjadi empat tahap, yaitu persiapan, sosialisasi dan pelatihan, pendampingan, dan evaluasi.

\section{A. Tahap Persiapan}

Observasi

Observasi dilakukan untuk menentukan lokasi eco-library yang aman dari bencana banjir rob serta dapat diakses oleh masyarakat. Tim peneliti bekerja sama dengan Kepala Desa Kilensari dalam menentukan lokasi yang cocok.

Pembentukan Tim Pelatih

Tim pelatih dibentuk untuk melatih calon manajer eco-library dalam mengelola buku dan kegiatan berbasis pengelolaan sampah yang akan dipandu secara online oleh Greenbooks.org. Tim pelatih terdiri dari dosen Fakultas Pertanian dan staf LPM Universitas Abdurachman Saleh Situbondo.

B. Tahap Sosialisasi dan Pelatihan

Sosialisasi Awal

Sosialisasi awal adalah sosialisasi kepada masyarakat pesisir. Sosialisasi kepada masyarakat pesisir ini dilakukan untuk memberikan pengetahuan awal akan pentingnya mengelola sampah dengan baik. Pemateri yang diundang adalah pakar di bidang pengelolaan sampah.

Pelatihan

Pelatihan yang dimaksud adalah pelatihan untuk mengelola eco-library dan kegiatan-kegiatan yang dapat dilakukan sebagai bentuk edukasi. Pelatihan ditujukan kepada anggota POKMASWAS Desa Kilensari yang ditunjuk sebagai manajer eco-library.

Sosialisasi Akhir

Sosialisasi akhir bertujuan untuk mempublikasikan keberadaan rumah baca yang memiliki koleksi buku-buku bertema pendidikan lingkungan, 
dengan target pembaca adalah anak-anak di Desa Kilensari yang berusia 6-18 tahun.

C. Tahap Pendampingan

Para pendamping pada tahap pendampingan ini adalah tim pelatih yang telah dibentuk pada tahap observasi. Proses pendampingan ini dilaksanakan selama masa pengabdian yaitu tiga bulan dan akan dilakukan sebulan sekali. Para pendamping diharapkan bisa mentransfer ilmu kepada masyarakat pesisir desa Kilensari, Panarukan, Kabupaten Situbondo.

Pelaporan Kegiatan Edukasi Lingkungan dan Kondisi Buku

Sebagian buku koleksi eco-library merupakan donasi dari Greenbooks.org, sebuah Lembaga Swadaya Masyarakat (LSM) yang berpusat di Bali dan bergerak di bidang edukasi lingkungan. Oleh karena itu, setiap eco-library penerima donasi buku harus memberikan laporan mengenai kegiatan-kegiatan edukasi lingkungan yang telah dilakukan serta kondisi buku-buku koleksi. Laporan diserahkan sebulan sekali melalui surat elektronik yang ditujukan kepada pendiri Greenbooks.org, yaitu Petr Henrich, dan disertai dokumentasi berupa foto atau video kegiatan edukasi lingkungan dan kondisi buku.

D. Tahap Evaluasi

Evaluasi dilakukan pada bulan ketiga berdasarkan capaian target luaran yang telah ditentukan

\section{HASIL DAN PEMBAHASAN}

Berdasarkan hasil wawancara dengan Kepala Desa Kilensari, telah ada rencana pembuatan TPS di Desa Kilensari yang akan segera dibangun pada tahun 2018 dengan luas total \pm 3 Ha. Hingga program ini selesai, tim pelaksana belum dapat berkontribusi dalam penentuan lokasi tempat pengumpulan sampah sementara (TPS) dikarenakan keterbatasan waktu dan biaya anggaran.

Sosialisasi dilakasanakan pada tanggal 15 November 2017 di Balai Desa Kilensari Kecamatan Panarukan. Jumlah peserta sosialisasi sebanyak 20 orang. Sosialisasi ini bertujuan untuk memperkenalkan eco-library dengan koleksi buku 
bertema lingkungan untuk anak-anak usia 6-12 tahun, serta beberapa kegiatan belajar bertema lingkungan.

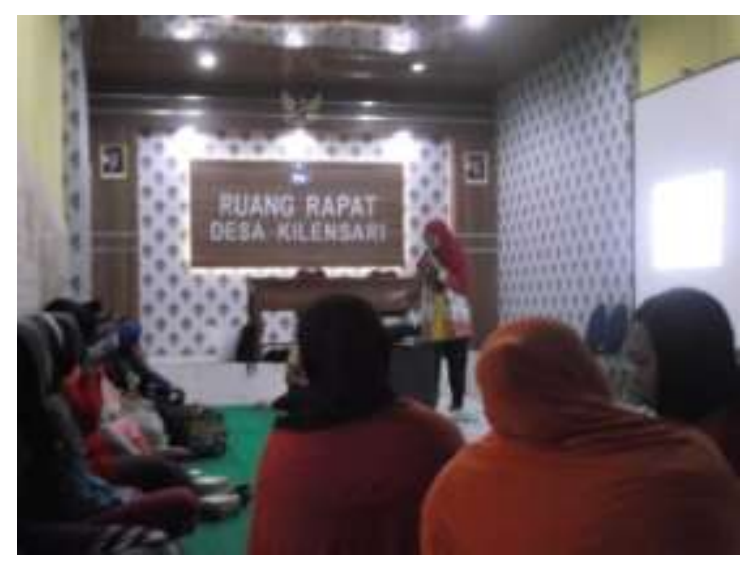

Gambar 2. Pemaparan materi sosialisasi

Masyarakat yang mengikuti kegiatan sosialisasi cukup antusias terhadap pendirian eco-library dan rencana kerja sama dengan Greenbooks.org untuk pembelajaran lingkungan kepada anak-anak. Antusiasme warga yang mengikuti kegiatan sosialisasi terlihat dengan pertanyaan-pertanyaan yang diajukan kepada narasumber. Diharapkan kegiatan-kegiatan sosialisasi dan pelatihan terkait pengelolaan sampah dapat berlanjut, sehingga masyarakat memahami dan melaksanakan pengelolaan sampah dengan benar.

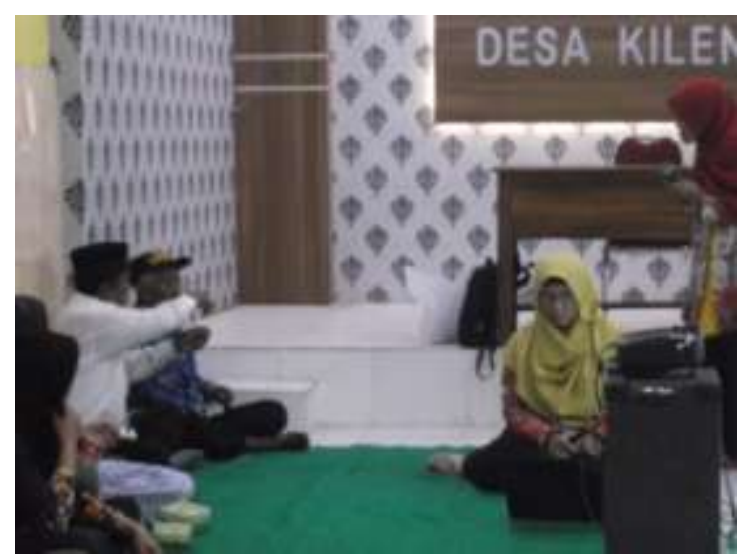

Gambar 3. Warga bertanya tentang cara mengurangi penggunaan kantong plastik saat kegiatan sosialisasi.

Pada awalnya eco-library dicanangkan memiliki koleksi buku-buku berbasis pengelolaan sampah dengan target pembaca anak-anak usia 6-18 tahun. Namun seiring berjalannya program, buku-buku tersebut tidak khusus membahas 
tentang pengelolaan sampah, namun masih bertema lingkungan dan makhluk hidup. Hal ini disebabkan karena ketersediaan buku-buku khusus pengelolaan sampah belum tersedia, sehingga tim pelaksana menyesuaikan tema yang masih berhubungan dengan lingkungan. Kerja sama dengan Greenbooks.org akan dimulai dengan pendaftaran rumah baca di Desa Kilensari.

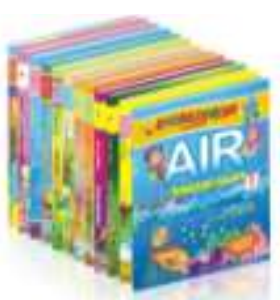

Seri Enslikopedia Anak Muslim Pengarang: Nurul Ihsan

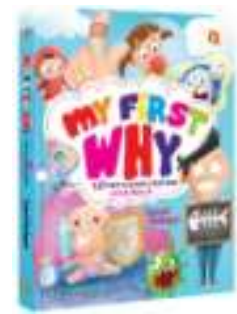

My First Why?

Pengarang: Susanti Domingues

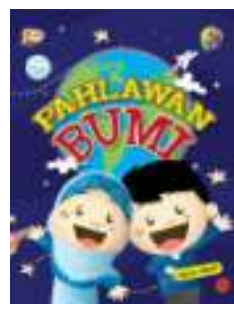

Pahlawan Bumi Pengarang: Fadila Hanum

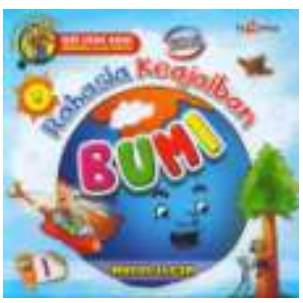

Seri Rahasia

Keajaiban Pengarang: Nurul Ihsan

Gambar 4. Buku-buku hibah PkM untuk eco-library di Desa Kilensari

Setelah terbentuk eco-library di Desa Kilensari Kecamatan Panarukan, diharapkan dapat meningkatkan minat baca anak-anak dan membentuk karakter/ kepribadian yang menjaga lingkungan. Untuk selanjutnya pengelolaan eco-library sedapatnya dipantau secara berkala. Adapun rencana pengembangan program kemitraan masyarakat yang dapat dilakukan setelah berdirinya eco-library ini adalah sebagai berikut.

a. Pendaftaran eco-library rumah baca di Desa Kilensari ke komunitas Greenbooks.org

b. Penambahan koleksi buku eco-library berbasis pengelolaan sampah di Desa Kilensari 
c. Pelatihan penerapan 3R (Reduce, Reuse, Recycle) di desa-desa pesisir Kabupaten Situbondo

d. Pelatihan dan Pembentukan Bank Sampah

\section{KESIMPULAN DAN SARAN}

Setelah dilaksanakan program kemitraan masyarakat ini dapat disimpulkan bahwa minat baca anak-anak sangat dipengaruhi oleh pengemasan isi buku yang menarik, yaitu dengan tulisan yang mudah dipahami dan disertai gambar-gambar. Tingkat pengetahuan masyarakat mengenai pengelolaan sampah, terutama sampah plastik, masih kurang. Kebiasaan pengurangan timbulan sampah plastik perlu terus digalakkan melalui sosialisasi dan pelatihan, serta didampingi secara berkelanjutan.

Sebaiknya dilakukan monitoring secara berkala terhadap pengelolaan ecolibrary (perawatan buku-buku). Diharapkan untuk dapat menambah koleksi buku eco-library melalui kerja sama dengan pemerintah daerah maupun swasta, serta dana hibah lainnya.

\section{DAFTAR PUSTAKA}

Damanhuri, E., dan Padmi, T., (2011), Pengelolaan Sampah, Diktat Kuliah TL3104, Program Studi Teknik Lingkungan Institut Teknologi Bandung (ITB).

Undang-undang Republik Indonesia Nomor 18 Tahun 2008 tentang Pengelolaan Sampah

https://www.beritalima.com/2016/12/13/puluhan-kk-panarukan-terpaksabegadang-akibat-banjir-rob/ 